\title{
Assessment of Natural Radioactivity Levels and Radiological Significance of Bottled Drinking Water in Bangladesh
}

\author{
M. Moshiur Rahman ${ }^{1, ~ *, ~ A p u r b a ~ M o n d a l ~}{ }^{1}$, M. A. Kabir ${ }^{1}$, K. Asaduzzaman ${ }^{2}$ \\ ${ }^{1}$ Department of Physics, Jahangirnagar University, Savar, Dhaka, Bangladesh \\ ${ }^{2}$ Nuclear Electronics Division, Institute of Electronics, Atomic Energy Research Establishment (AERE), Savar, Dhaka, Bangladesh
}

Email address:

phy_mmr@juniv.edu (M. M. Rahman)

\section{To cite this article:}

M. Moshiur Rahman, Apurba Mondal, M. A. Kabir, K. Asaduzzaman. Assessment of Natural Radioactivity Levels and Radiological Significance of Bottled Drinking Water in Bangladesh. American Journal of Physics and Applications. Vol. 3, No. 6, 2015, pp. $203-207$. doi: 10.11648/j.ajpa.20150306.13

\begin{abstract}
This study deals with the assessment of natural radioactivity due to ${ }^{226} \mathrm{Ra},{ }^{232} \mathrm{Th}$ and ${ }^{40} \mathrm{~K}$ in bottled drinking water samples, marketed in Bangladesh. High purity germanium (HPGe) detector based spectrometry system coupled with Multi Channel Analyzer (MCA) was used to obtain gamma-ray spectra. The mean concentrations of ${ }^{226} \mathrm{Ra}$, ${ }^{232} \mathrm{Th}$ and ${ }^{40} \mathrm{~K}$ were found to be $3.28 \pm 2.10,6.40 \pm 2.92$ and $18.26 \pm 17.49 \mathrm{~Bq} . \mathrm{L}^{-1}$ respectively. The committed effective doses due to ingestion of natural radionuclides from the consumption of bottled water for four different age groups were estimated. The annual cumulative effective doses due to all three natural radionuclides for different age groups of children (2-7 y), 7-12 y, 12-17 y and adults ( $>17$ y) were estimated to be $1.54,2.07,3.41$ and $1.83 \mathrm{mSv} \mathrm{y}^{-1}$ respectively. Among the three natural radionuclides, annual effective doses due to intake of ${ }^{226} \mathrm{Ra}$ for age groups $7-12 \mathrm{y}$ and $12-17 \mathrm{y}$ are significant. For children $(2-7 \mathrm{y})$ and adults $(>17 \mathrm{y})$, annual effective doses due to intake of ${ }^{232} \mathrm{Th}$ are significant. The obtained results are compared with the reported and recommended values from other countries and international organizations respectively. However, annual estimated effective doses for all four age groups from the intake of natural radionuclides in bottled drinking water were higher than the World Health Organisation (WHO) recommended limit of $0.10 \mathrm{mSvy}^{-1}$ as well as the average radiation dose of $0.29 \mathrm{mSvy}^{-1}$ received per head worldwide due to ingestion of natural radionuclides assessed by UNSCEAR -2000.
\end{abstract}

Keywords: MCA, HPGe Detector, Natural Radioactivity, Effective Dose, Radiation Exposure and Radio-Nuclides

\section{Introduction}

Natural radioactivity is always present in the environment, so water is not free of radioactive isotopes from naturally decaying series of ${ }^{235} \mathrm{U},{ }^{238} \mathrm{U},{ }^{232} \mathrm{Th}$ and ${ }^{40} \mathrm{~K}$. Sales and consumption of bottled water have been skyrocketed globally in recent years. In USA the bottled water sales are increased $4.5 \%$ in 2013 than previous year, while the fruit beverage and carbonated drinks are declined at $1.9 \%$ and $3.2 \%$ respectively [1]. Now a days, bottled water is the second-largest beverage type sold in the world market. Consumers are paying thousand times higher prices for bottled water than municipal tap water, owing to growing awareness over the contaminated drinking water related diseases. The kind of treatment applied to purify different brands of bottled water in Bangladesh does not touch the problem of radioactivity. Monitoring of natural radioactivity in drinking water is an important parameter for public health studies, which allows the assessment of population exposure to radiation by the consumption of water [2]. An average radiation dose of $0.29 \mathrm{mSvyr}^{-1}$ is received worldwide via ingestion of natural radionuclides of ${ }^{238} \mathrm{U}$ and ${ }^{232} \mathrm{Th}$ series and ${ }^{40} \mathrm{~K}$ during habitual consumption of food and water [3]. Even small amounts of ingested or inhaled radioactivity may produce a damaging effect and can become a serious health risk [4]. Most of the bottled mineral water manufacturers are not processing and bottling water according to the WHO and the International Bottling Water Association guidelines [5]. In Bangladesh some studies have been taken on the measurement of radon in houses and natural and artificial radioactivity in building materials and soils to evaluate the potential health hazards for the dwelling population [6-11]. However, no data have been reported with respect to natural radioactivity levels in the bottled drinking water. The 
information is essential for the development of standards and guidelines for the use and management of bottled drinking water in Bangladesh. This study represents data on most commonly sold bottled drinking water brands in Bangladesh. The generated data may contribute to establish the base-line levels of natural radioactivity in drinking water and help in the development of future guidelines for radiological protection.

\section{Materials and Methods}

\subsection{Sample Collection and Preparation}

The water samples of different brands like Mum, Spa, Fresh, Acme, Jibon, Shanti, Pani, Ifad and Pran were collected from local markets in and around Dhaka city. Approximately $260 \mathrm{ml}$ of each sample was sealed in gas tight, radon impermeable cylindrical plastic containers and were sealed hermetically to ensure that all daughter products of ${ }^{238} \mathrm{U}$ and ${ }^{232} \mathrm{Th}$, in particular gaseous radon isotopes did not escape. These samples were then stored for $5-6$ weeks before counting so as to ensure Ra and its short-lived progeny to reach secular equilibrium.

\subsection{Gamma Spectrometry}

Gamma spectrometry was performed by HPGe detector with relative efficiency of $20 \%$ and resolution (FWHM) 1.8 $\mathrm{keV}$ at $1332 \mathrm{keV} \gamma$-energy of ${ }^{60} \mathrm{Co}$, connected to a MCA, to measure the concentration of natural radioactivity $(\mathrm{Ra}, \mathrm{Th}$ and $\mathrm{K})$ in the samples. Spectral data from the detector was accumulated on an MCA and analyzed using Genie-2000 software from Canberra. The energy calibration was carried out by counting the radioactive standards of known energies such as ${ }^{60} \mathrm{Co}$, for $\mathrm{E}_{\gamma}=1173.2$ and $1332.5 \mathrm{keV}$, and ${ }^{137} \mathrm{Cs}$, for $\mathrm{E}_{\gamma}$ $=661.6 \mathrm{keV}$. The efficiency calibration was performed by using point source of ${ }^{152} \mathrm{Eu}$. Assuming secular equilibrium in the uranium and thorium decay series, the ${ }^{226} \mathrm{Ra}$ and ${ }^{232} \mathrm{Th}$ activities were determined indirectly via the activities of their daughter products. The choice of the reference nuclides was made so that the related peaks were sufficiently discriminated and intense. The content of ${ }^{226} \mathrm{Ra}$ was measured using $\gamma$-energy of $295.18 \mathrm{keV}(18.15){ }^{214} \mathrm{~Pb}, 351.92 \mathrm{keV}$ (35.10) ${ }^{214} \mathrm{~Pb}, 609.35 \mathrm{keV}(44.60){ }^{214} \mathrm{Bi}, 1120.5 \mathrm{keV}(14.70){ }^{214} \mathrm{Bi}$ and $1764.5 \mathrm{keV}$ (15.10). The contents of ${ }^{232} \mathrm{Th}$ was determined using $238.76 \mathrm{keV}$ (43.50) ${ }^{212} \mathrm{~Pb}, 583.24 \mathrm{keV}(30.70){ }^{208} \mathrm{Tl}$, $911.32 \mathrm{keV}(26.60){ }^{228} \mathrm{Ac}, 969.19 \mathrm{keV}(16.23){ }^{228} \mathrm{Ac}$ and $2613.2 \mathrm{keV}(35.60){ }^{208} \mathrm{Tl}$. The daughter products of ${ }^{226} \mathrm{Ra}$ and ${ }^{232} \mathrm{Th}$ in all samples were omitted from our consideration because either their activities were below the detection limit or their peaks were of bad shapes.

\subsection{Activity}

The activity concentrations of the samples were calculated using the following formula,

$$
\mathrm{A}=(\mathrm{CPS} \times 1000) /(\mathrm{E} \times \mathrm{I} \times \mathrm{W})
$$

Where, $\mathrm{A}=$ Activity of the sample in Bq. $\mathrm{kg}^{-1}$, CPS $=$ Net count per second (CPS for sample - CPS for background value)

$\mathrm{E}=$ Counting efficiency, $\mathrm{I}=$ Absolute intensity of the gamma ray,

$\mathrm{W}=$ Weight of the sample $(\mathrm{ml})$

The errors of the measurement have been expressed in terms of standard deviation $( \pm 2 \sigma)$ which is expressed as

$$
26=\left[\mathrm{N}_{\mathrm{S}} / \mathrm{T}_{\mathrm{S}}^{2}+\mathrm{N}_{\mathrm{b}} / \mathrm{T}_{\mathrm{b}}^{2}\right]
$$

Where, $\mathrm{N}_{\mathrm{S}}$ is the sample counts measured in time $\mathrm{T}_{\mathrm{S}}$ and $\mathrm{N}_{\mathrm{b}}$ is the background counts measured in time $T_{b}$.

\subsection{Effective Dose}

The annual effective dose to an individual due to intake of natural radionuclides from the bottled drinking water was estimated using the following relationship [12]

$$
\mathrm{D}_{\mathrm{w}}=\mathrm{C}_{\mathrm{w}} \mathrm{CR}_{\mathrm{w} .} \mathrm{D}_{\mathrm{cw}}
$$

$D_{w}$ is the annual effective dose $\left(\mathrm{Svy}^{-1}\right)$ due to ingestion of radionuclides from the consumption of bottled water, $\mathrm{C}_{\mathrm{w}}$ is the activity concentration of radionuclides in the ingested drinking water $\left(\mathrm{BqL}^{-1}\right), \mathrm{CRw}$ is the annual intake of drinking water $\left(\mathrm{Ly}^{-1}\right), \mathrm{D}_{\mathrm{cw}}$ is the ingested dose conversion factor for public $\left(\mathrm{SvBq}^{-1}\right) . \mathrm{D}_{\mathrm{cw}}$ values used in the calculations are taken from NRBP-R245 [13]. Annual effective dose due to intake of natural radionuclides from bottled drinking water has been calculated keeping in view the different age groups from $2-7 y$, $7-12 y, 12-17 y$ and $>17 y$. For this study, the annual average intake of bottled drinking water is considered to be 328,440 , 512 and 730 litres for the age groups of $2-7 y, 7-12 y, 12-17 y$ and adults of age $>17 \mathrm{y}$ respectively [3]. The age-dependent effective dose per litre $\left(\mu \mathrm{Sv} \mathrm{L}^{-1}\right)$ and annual effective dose $\left(\mathrm{mSvy}^{-1}\right)$ were calculated.

\section{Results and Discussions}

The natural radioactivity concentrations of ${ }^{226} \mathrm{Ra},{ }^{232} \mathrm{Th}$ and ${ }^{40} \mathrm{~K}$ in different bottled drinking water samples available in Bangladesh are presented in the figure-1. It is observed that the activity concentration in bottled drinking water samples due to ${ }^{226} \mathrm{Ra}$ varies from $1.88 \pm 2.22$ to $4.97 \pm 1.38$ Bq.L ${ }^{-1}$ with an average of $3.28 \pm 2.10 \mathrm{~Bq} . \mathrm{L}^{-1}$, due to ${ }^{232} \mathrm{Th}$ varies from $1.42 \pm 2.99$ to $9.72 \pm 3.04 \mathrm{~Bq} . \mathrm{L}^{-1}$ with an average of $6.40 \pm 2.92$ Bq. $\mathrm{L}^{-1}$ and due to ${ }^{40} \mathrm{~K}$ varies from $10.88 \pm 17.52$ to $32.24 \pm 17.02$ Bq. $\mathrm{L}^{-1}$ with an average of $18.26 \pm 17.49$ Bq.L $\mathrm{L}^{-1}$. Figure-1 shows that the activity concentration of ${ }^{226} \mathrm{Ra},{ }^{232} \mathrm{Th}$ and ${ }^{40} \mathrm{~K}$ in all samples are varied randomly which may be attributed to the mineral contents and other chemical parameters of the drinking water. It also indicates that the highest activity is due to ${ }^{40} \mathrm{~K}$ in all samples. After that, most of the samples, specifically seven of them show higher activity of ${ }^{232} \mathrm{Th}$ than that of ${ }^{226} \mathrm{Ra}$. As a whole, from Figure-1, the activity concentration of thorium is found to be higher than radium, which is evident from the fact that thorium is 1.5 times higher than that of uranium in earth's crust [14]. WHO and the United States Environmental Protection Agency recommendations allow a maximum ${ }^{226} \mathrm{Ra}$ concentration in drinking water of 
1000 and $185 \mathrm{mBq} . \mathrm{L}^{-1}$ respectively [15]. The measured mean value of ${ }^{226} \mathrm{Ra}$ concentration of $3.28 \pm 2.10 \mathrm{~Bq} . \mathrm{L}^{-1}$ appears much higher than both of these two recommended limits.

The obtained ${ }^{226} \mathrm{Ra}$ concentration is compared with those obtained by other researchers in abroad and WHO permissible limit as shown in Figure-2. The measured ${ }^{226} \mathrm{Ra}$ activity concentration is almost equal to the concentrations observed in Spain and Hungary, higher than those of observed in Pakistan, Turkey, Poland, Finland and Croatia; lower than those observed in Jordan, Nigeria and Tunisia. Besides, the obtained average ${ }^{232} \mathrm{Th}$ concentration is higher than that of observed in Pakistan. Also, the obtained average ${ }^{40} \mathrm{~K}$ concentration is higher than those of observed in Pakistan, Turkey, Hong Kong and Nigeria.

\section{Annual Effective Doses}

Radionuclide may reach the gastrointestinal tract directly by ingestion or indirectly by transfer from the respiratory tract. From small intestine the radionuclide can be absorbed to the body fluids. The quantities commonly used for estimating the exposure to population from terrestrial radionuclides are effective dose and the annual effective dose. Owing to the intake of ${ }^{226} \mathrm{Ra}$, the effective dose and annual effective dose has been estimated which vary from 1.17 to $3.08 \mu \mathrm{SvL}^{-1}$ and 0.38 to $1.01 \mathrm{mSvy}^{-1}$ with averages of $2.03 \mu \mathrm{SvL}^{-1}$ and 0.67 $\mathrm{mSvy}^{-1} ; 1.50$ to $3.98 \mu \mathrm{SvL}^{-1}$ and 0.66 to $1.75 \mathrm{mSvy}^{-1}$ with averages of $2.62 \mu \mathrm{Sv} \mathrm{L}^{-1}$ and $1.15 \mathrm{mSv} \mathrm{y}^{-1} ; 2.82$ to $7.46 \mu \mathrm{SvL}^{-1}$ and 1.44 to $3.82 \mathrm{mSvy}^{-1}$ with averages of $4.92 \mu \mathrm{SvL}^{-1}$ and 2.52 $\mathrm{mSvy}^{-1}$; and 0.53 to $1.39 \mu \mathrm{SvL}^{-1}$ and 0.38 to $1.02 \mathrm{mSvy}^{-1}$ with averages of $0.92 \mu \mathrm{SvL}^{-1}$ and $0.67 \mathrm{mSvy}^{-1}$ for age groups of 2 $7 \mathrm{y}, 7-12 \mathrm{y}, 12-17 \mathrm{y}$ and $>17 \mathrm{y}$, respectively. Due to the intake of ${ }^{232} \mathrm{Th}$, the effective dose and annual effective dose vary from 0.50 to $3.40 \mu \mathrm{Sv} \mathrm{L}^{-1}$ and 0.16 to $1.12 \mathrm{mSv} \mathrm{y}^{-1}$ with averages of $2.24 \mu \mathrm{Sv} \mathrm{L}^{-1}$ and $0.74 \mathrm{mSv} \mathrm{y}^{-1} ; 0.41$ to $2.82 \mu \mathrm{Sv}$ $\mathrm{L}^{-1}$ and 0.18 to $1.24 \mathrm{mSv} \mathrm{y}^{-1}$ with averages of $1.85 \mu \mathrm{Sv} \mathrm{L}^{-1}$ and $0.82 \mathrm{mSv} \mathrm{y}^{-1} ; 0.36$ to $2.43 \mu \mathrm{Sv} \mathrm{L}^{-1}$ and 0.18 to $1.24 \mathrm{mSv}^{-1}$ with averages of $1.60 \mu \mathrm{Sv} \mathrm{L}^{-1}$ and $0.82 \mathrm{mSv} \mathrm{y}^{-1}$; and 0.33 to $2.24 \mu \mathrm{Sv} \mathrm{L}^{-1}$ and 0.24 to $1.63 \mathrm{mSv} \mathrm{y}^{-1}$ with averages of 1.47 $\mu \mathrm{Sv} \mathrm{L} \mathrm{L}^{-1}$ and $1.08 \mathrm{mSv} \mathrm{y}^{-1}$ for age groups of 2-7 y, 7-12 y, 12$17 \mathrm{y}$ and $>17 \mathrm{y}$, respectively. The effective dose and annual effective dose due to ${ }^{40} \mathrm{~K}$, vary from 0.23 to $0.68 \mu \mathrm{Sv} \mathrm{L}^{-1}$ and 0.08 to $0.22 \mathrm{mSv} \mathrm{y}^{-1}$ with averages of $0.38 \mu \mathrm{Sv} \mathrm{L} \mathrm{L}^{-1}$ and 0.13 $\mathrm{mSv} \mathrm{y}^{-1} ; 0.14$ to $0.42 \mu \mathrm{Sv} \mathrm{L}^{-1}$ and 0.06 to $0.18 \mathrm{mSv} \mathrm{y}^{-1}$ with averages of $0.24 \mu \mathrm{Sv} \mathrm{L}^{-1}$ and $0.10 \mathrm{mSv} \mathrm{y}^{-1} ; 0.08$ to $0.25 \mu \mathrm{Sv}$ $\mathrm{L}^{-1}$ and 0.04 to $0.13 \mathrm{mSv} \mathrm{y}^{-1}$ with averages of $0.14 \mu \mathrm{Sv} \mathrm{L}^{-1}$ and $0.07 \mathrm{mSv} \mathrm{y}^{-1}$; and 0.07 to $0.20 \mu \mathrm{Sv} \mathrm{L}^{-1}$ and 0.05 to $0.15 \mathrm{mSv}$ $\mathrm{y}^{-1}$ with averages of $0.11 \mu \mathrm{Sv} \mathrm{L}{ }^{-1}$ and $0.08 \mathrm{mSv} \mathrm{y}^{-1}$ for age groups of 2-7 y, 7-12 y, 12-17 y and $>17 \mathrm{y}$, respectively.

${ }^{226} \mathrm{Ra}$ is a highly radiotoxic and $\sim 20 \%$ is absorbed into the blood stream after the ingestion into human body. The absorbed radium is initially distributed to soft tissues and bones, but its retention is mainly in growing bones [16)]. From Figure-4 and Figure-5, it has been observed that effective dose and annual effective dose due to ${ }^{226} \mathrm{Ra}$ is much higher for the age group of $12-17 y$ than that of all other age groups. Whereas effective dose and annual effective dose due to ${ }^{232} \mathrm{Th}$ is higher for adults ( $>17 \mathrm{y})$ and Keeping an eye in the same way, the effective dose and annual effective dose due to ${ }^{40} \mathrm{~K}$ is higher for children (2-7 y). Furthermore, the cumulative average annual effective doses due to the intake of natural radionuclides are compared with the WHO permissible limit as in figure -6. It is evident from figure the cumulative annual effective doses due to activity of natural radionuclides, ${ }^{226} \mathrm{Ra}$, ${ }^{232} \mathrm{Th}$ and ${ }^{40} \mathrm{~K}$, in bottled drinking water samples for all four different age groups are higher than the recommended limit of $0.1 \mathrm{mSv}^{-1} \mathrm{y}^{-1}$ for drinking water [17] as well as the average radiation dose of $0.29 \mathrm{mSv} \cdot \mathrm{y}^{-1}$ received per head world-wide due to the ingestion of natural radionuclides [3]. For all of the age groups, the annual effective dose in Bangladesh are higher than those of observed in Pakistan, Malaysia and Egypt; almost equal to those of obtained in Jordan and Nigeria for children and adults; and lower than those of observed in Tunisia for children. Since all the samples carry a significant amount of radionuclide, further research works should be continued and regular monitoring is necessary to save people from the chronic exposure.

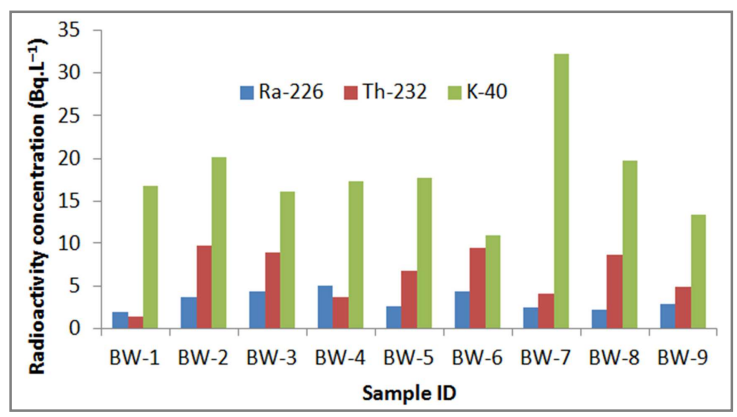

Figure 1. Activity Concentration of ${ }^{226} \mathrm{Ra},{ }^{232} \mathrm{Th}$ and ${ }^{40} \mathrm{~K}$ in different samples.

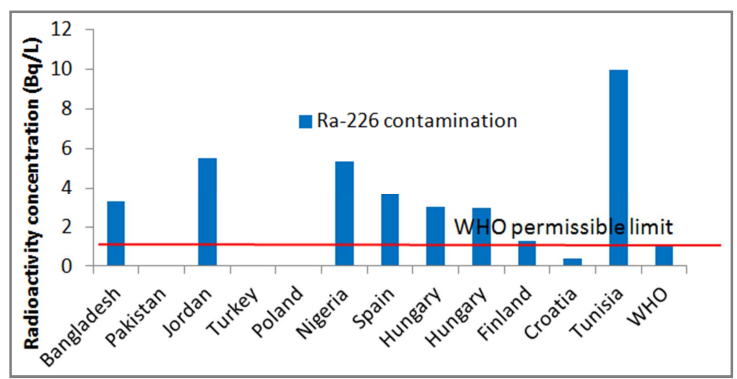

Figure 2. Comparison of activity Concentration due to ${ }^{226} \mathrm{Ra}$ in several countries and standard values.

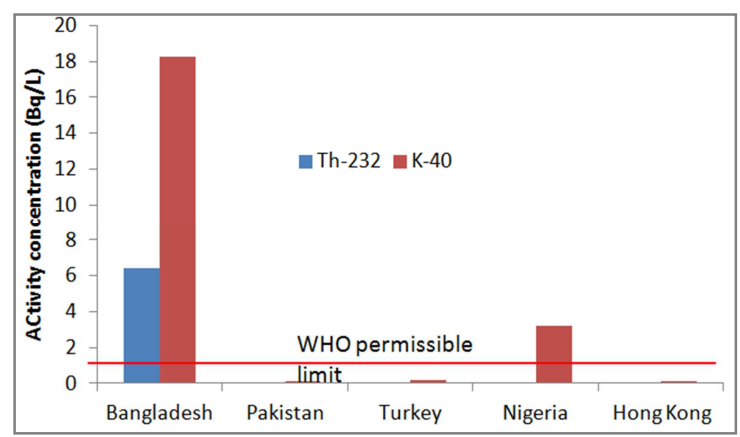

Figure 3. Comparison of activity Concentration due to ${ }^{232} \mathrm{Th}$ and ${ }^{40} \mathrm{~K}$ in several countries and standard values 


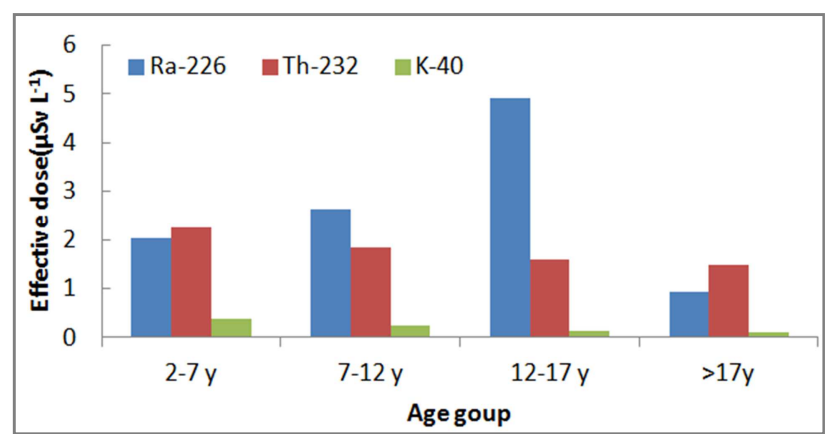

Figure 4. Average effective doses per litre due to ${ }^{226} \mathrm{Ra},{ }^{232} \mathrm{Th}$ and ${ }^{40} \mathrm{~K}$ for different age limit.

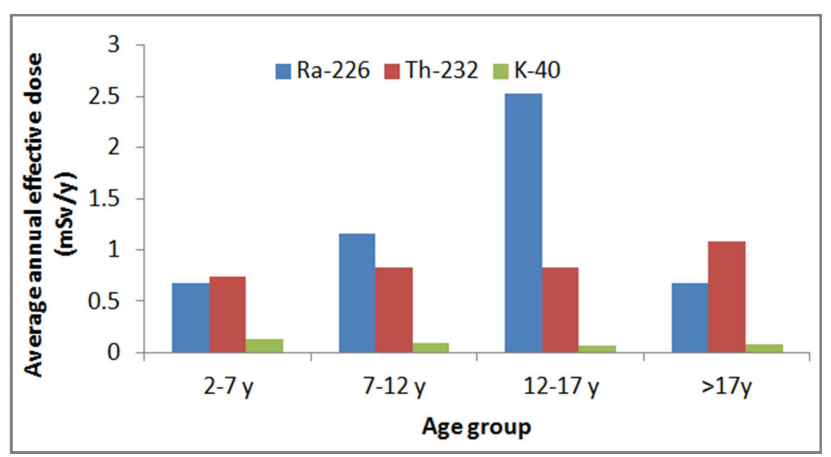

Figure 5. Average annual effective doses per litre due to ${ }^{226} \mathrm{Ra},{ }^{232} \mathrm{Th}$ and ${ }^{40} \mathrm{~K}$ for different age limit

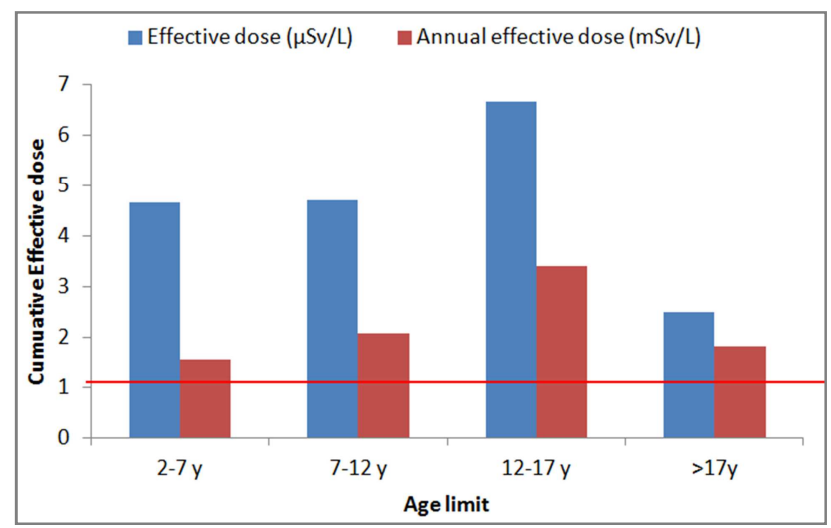

Figure 6. Cumulative effective doses due to ${ }^{226} \mathrm{R} a,{ }^{232} \mathrm{Th}$ and ${ }^{40} \mathrm{~K}$ for different age limit.

\section{Conclusion}

The natural radioactivity in bottled drinking water samples, the effective dose equivalent and annual effective dose corresponding to four different population groups based on their age have been estimated by the gamma spectroscopy. It has been observed that annual effective doses for all four different age groups are higher than the WHO recommended limit of $0.1 \mathrm{mSv}^{-1} \mathrm{y}^{-1}$ for drinking water as well as the average radiation dose of $0.29 \mathrm{mSv} . \mathrm{y}^{-1}$ received per head world-wide due to the ingestion of natural radionuclides assessed by UNSCEAR-2000 though the average annual effective doses are below the maximum permissible limit of $5 \mathrm{mSv} \mathrm{y}^{-1}$ for public. The data generated in this study will provide base-line radiometric values of bottled drinking water in Bangladesh and may help in setting the national guidelines for natural radionuclides and permissible annual effective dose in the bottled drinking water.

\section{References}

[1] Beverage Marketing Corporation (2014); The U.S. Liquid Refreshment Beverage Market Remained Flat in 2013; 29 December 2014; (http://www.beveragemarketing.com/news-detail.asp?id=299).

[2] Isam Salih MM., Pettersson HB, and Lund E.; "Uranium and Thorium Series Radionuclides in Drinking Water from Drilled Bedrock Wells: Correlation to Geology and Bedrock Radioactivity and Dose Estimation"; Radiat. Prot. Dosim. 102(3) (2002), 249-258.

[3] United Nations Scientific Committee on the Effects of Atomic Radiation. Sources and Effects of Ionizing Radiation. Report to the General Assembly (NY: UN) (2000).

[4] Rowland RE.; "Low-Level Radium Retention by the Human Body: A Modification of the ICRP Publication 20 Retention Equation" Health Phys. 65(5) (1993), p.507-13.

[5] International Bottled Association (IBWA). Code of Practice. Revised March, 2005.

[6] Chowdhury I. M., M. N. Alam, and A. K. S. Ahmed; (1998), "Concentration of Radionuclides in Building and Ceramic Materials of Banglesh and Evaluation of Radiation Hazard". J. Radioanal. Nucl. Chem. 231(1-2), 117-122.

[7] Alam M. N(b), M. M. H. Miah, M. I. Chowdhury, M. Kamal, S. Ghose, M. N. Islam, M. Mustafa and M. S. R. Miah, 1999, Radiation Dose Estimation from the Radioactivity Analysis of Lime and Cement used in Bangladesh. J. Environ. Radioact. 42, pp 77-85.

[8] Mollah A. S., G. U. Ahmed, S. R. Husain, and M. M. Rahman, 1986, The Natural Radioactivity of Some Building Materials used in Bangladesh. Health Phys. 50(6), pp 849-851.

[9] Roy S., M. S. Alam, F. K. Miah and B. Alam, Concentrations of Naturally Occurring Radionuclides and Fission Products in Brick Samples Fabricated and Used, in and around Greater Dhaka City. Radiation Protection Dosimetry Vol. 88, No. 3, pp. 255-260. Nuclear Technology Publishing, 2000.

[10] Roy S., M. S. Alam, M. Begum and B. Alam (2005), Radioactivity in Building Materials used in and around Dhaka City, Radiation Protection Dosimetry, volume 114, pp 527-532.

[11] Alam M. N(a), M. I. Chowdhury, M. Kamal, S. Ghose, M. N. Islam, M. N. Mustafa and P. Roy, Radioactivity in Soil of Chittagong Hill, Nuclear Science and Applications, BAEC, Volume 4, No 1, 1995.

[12] Alam M.N(c)., M.I. Chowdhury, M. Kamal, S. Ghose, M.N. Islam and M. Anwaruddin, Radiological Assessment of Drinking Water of The Chittagong Region of Bangladesh, Radiation Protection Dosimetry 82/3 (1999), pp 207-214.

[13] Phipps, A. W., Kendall, G. M., Stather, J.W. and Fell, T. P. Committed Effective Doses from ontakes Of Radionuclides. NRPB-R245 (Chilton, Didcot, Oxon: NRPB) (1991).

[14] Aswathanarayana U (1985). Principles of Nuclear Geology. Ozonian Press Pvt. Ltd., New Delhi, pp 85-87. 
[15] Fredj A. Ben, N. Hizem, M. Chelbi, and L. Ghedira, Quantitative analysis of gamma-ray emitters radionuclides in commercial bottled water in Tunisia, Radiation Protection Dosimetry, 117/4 (2005), pp 419-424.

[16] Arabi A. M. El, N. K. Ahmed and K. Salahel Din, Natural Radionuclides and Dose Estimation in Natural Water Resources from Elba Protective Area, Egypt. Radiat. Prot.
Dosim. Doi: 1093/Rpd/Ncl022, Advance Access Published on Feb 23, 2006.

[17] World Health Organization. Guidelines for drinking water quality (Geneva: WHO), 1993. 